\title{
Heterologous Expression of the Alba Protein from the Hyperthermophilic Archaeon Aeropyrum Pernix
}

\author{
Miha Črnigoj, ${ }^{a}$ Andrej Hanzlowsky, ${ }^{a}$ Tanja Vilfan, ${ }^{a}$ and Nataša Poklar Ulrih ${ }^{\text {a,b,* }}$ \\ ${ }^{a}$ Department of Food Science and Technology, Biotechnical Faculty, University of Ljubljana, \\ Jamnikarjeva 101, 1000 Ljubljana, Slovenia \\ ${ }^{\mathrm{b}}$ CipKeBiP - The Centre of Excellence for Integrated Approaches in Chemistry and Biology of Proteins, \\ Jamova 39, 1000 Ljubljana, Slovenia
}

\begin{abstract}
Nucleic acid binding proteins have important roles in DNA and RNA packaging, stabilisation and repair, and in gene regulation, and they are therefore essential for all organisms. All of the known hyperthermophiles have at least one DNA sequence encoding for the Alba proteins. The Alba proteins are small (approximately $10 \mathrm{kDa}$ ), DNA-binding, basic proteins that appear to partly compensate for the lack of histones in the archaea Aeropyrum pernix and other hyperthermophiles. Two sequences of these potential histone counterparts, the Alba proteins, were identified in the Aeropyrum pernix genome (APE1832.1 and APE1823). By using a wide range of experimental techniques and by examining several combinations of expression systems the expression of recombinant Alba1 and Alba2 proteins was optimized. Co-expression of both of the Alba proteins was needed when isolating recombinant Alba2. The purification of both recombinant Alba1 and Alba2 His-tagged proteins were simplyfied in satisfactory yield. The electrophoretic mobility shift assay demonstrated the ability of the Alba1 and Alba2 proteins from Aeropyrum pernix to bind DNA. (doi: 10.5562/cca1772)
\end{abstract}

Keywords: Aeropyrum pernix, hyperthermophile, archaea, Alba, DNA binding, DNA stabilisation

\section{INTRODUCTION}

Archaea are one of three presently recognised phenotypical domains ${ }^{1}$ and they are widely known for their ability to inhabit extreme habitats. The cell components of hyperthermophiles could be exposed to heat denaturation, and they must therefore be protected at many levels. Archaeal nucleic acids are usually stabilised with a combination of different stabilisation mechanisms, which include higher GC content (\%) in their RNA molecules, binding of cations and polyamines, covalent modifications of mainly RNA molecules, compact tertiary structures of nucleic acids, binding of thermostable proteins, and efficient repair systems. ${ }^{2}$ Besides histones, the most widespread DNAbinding proteins are the Alba proteins, which are present in all known hyperthermophiles. ${ }^{3}$ Aeropyrum pernix is a hyperthermophilic crenarchaeon, and it is a strictly aerobic organism with an optimal growth temperature of around $90^{\circ} \mathrm{C}$. A. pernix contains no known histones. ${ }^{4,5}$ The histone function is believed to be carried out by other proteins, such as the $10 \mathrm{kDa}$ small basic proteins in archaea (the Alba proteins) and other basic protein families (e.g. $7 \mathrm{kDa}$ small basic proteins). ${ }^{6-10}$

Two Alba protein sequences were identified in the A. pernix genome, APE1832.1 (Alba1) and APE1823 (Alba2), which appear to originate from gene duplication. ${ }^{11}$ The Albal protein consists of 94 amino acid residues $(10.3 \mathrm{kDa} ; \mathrm{pI}=9.5)$, while Alba2 consists of 102 amino acid residues $(11.4 \mathrm{kDa}, \mathrm{pI}=9.1) .{ }^{3,12}$ Like the Alba proteins from other archaea, structurally, both of these A. pernix Alba proteins resemble the C-terminal domain of bacterial initiation factors. ${ }^{3,12-14}$ It is known that the Alba proteins from some hyperthermophiles can constrain supercoiling in the structure of the DNA molecules at high temperatures, when a critical concentration of these proteins is exceeded. ${ }^{9}$ Another potential mechanism of DNA stabilisation and chromatin regulation resides in the distinct DNA conformation in archaea. ${ }^{6,9}$

The aim of this study was to optimize the expression of both recombinant proteins Alba1 and Alba2 by using a wide range of experimental techniques and by examining several combinations of expression systems and to simplify the purification of both His-tagged proteins and to demonstrate their ability to bind DNA.

\footnotetext{
* Author to whom correspondence should be addressed. (E-mail: natasa.poklar@bf.uni-lj.si)
} 
Table 1. Primer sequences used for APE 1832.1 and APE1823

\begin{tabular}{ll}
\hline Primer & Primer sequence \\
\hline APE1823-F & 5'- TAATgAggATCCATggCATgTgAgggAgC -3' \\
APE1823-R & 5'- TTCAgTgAATTCTTAggCAgACTCgCCCg -3' \\
APES060-F & 5'- TCgTgAggATCCATgTACAgCgTAgTgTCg -3 \\
APES060-RPst & 5'- CCgggAgAATTCCCTAgCCTTTAgCAAC -3' \\
APE1823-RPstI & 5'- TTACgACTgCAgTTAggCAgACTCgCCC -3' \\
APE1832.1-F & 5'- gTAAgAggATCCATgTCgATAgAgCCgCAg -3' \\
APE1832.1-R & 5'- CCCgCACTgCAgCTAgCCTTTAgCAACTAC -3' \\
APE1823-F-BamHI & 5'- TTAAgAggATCCgATggCATgTgAgggAgCAC -3' \\
APE1823-R-PstI & 5'- TTACgACTgCAgTTAggCAgACTCgCCCgC -3' \\
APE1832.1-F-NdeI & 5'- gTAAgACATATggTgTCgATAgAgCCgCAgAA -3' \\
APE1832.1-R-BglII & 5'- CCCgCAAgATCTCTAgCCTTTAgCAACTACAATT -3' \\
\hline
\end{tabular}

\section{EXPERIMENTAL}

\section{Cloning and Expression}

Aeropyrum Pernix Genomic DNA Isolation

A. pernix cultures were grown to late-exponential phase at $92{ }^{\circ} \mathrm{C}$. After biomass collection by centrifugation $(4000 \times \mathrm{g}$, $20 \mathrm{~min}, 4^{\circ} \mathrm{C}$ ), the genomic DNA was isolated as previously described. ${ }^{15}$ Several cycles of additional chloroformphenol purification of the DNA were performed (up to eight successive extractions), until no inter-phase impurities were seen. The concentrations of the DNA were ex-

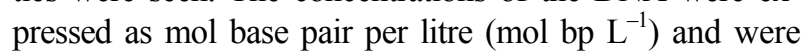
determined spectrophotometrically (HP 8453 spectrophotometer; Hewlett Packard, Palo Alto, USA) at $260 \mathrm{~nm}$ and $25{ }^{\circ} \mathrm{C}$, using $\varepsilon_{260}=12800 \mathrm{M}^{-1} \mathrm{~cm}^{-1}$. The $A_{260} / A_{280}$ ratio of the isolated DNA was $1.73 \pm 0.02$.

\section{Preparation of DNA Fragments for Alba Proteins}

The APE1832.1 and APE1823 sequences were amplified via PCR reactions using the A. pernix genomic DNA as template. The PCR amplifications included: denaturation at $95{ }^{\circ} \mathrm{C}(1 \mathrm{~min})$, annealing at $65{ }^{\circ} \mathrm{C}$ $(1 \mathrm{~min})$, and elongation at $72{ }^{\circ} \mathrm{C}(2 \mathrm{~min})$. This reaction sequence was repeated 40 times ( 40 cycles).

\section{Glutathione-S-transferase-tagged Products}

For cloning of glutathione S-transferase (GST)-tagged proteins, the following primers were used: APES060-F and APES060-RPst for amplification of the APES060 sequence (this sequence is 12 nucleotides longer than that of APE1832.1, at the 5' end), and APE1823-F and APE1823-R for amplification of the APE1823 sequence (Table 1). The sequences for the Alba proteins were cloned into the pGEX expression plasmid, which was transformed (TransformAid kit, Fermentas) into the M15 Escherichia coli expression strain.

Cloning of His-tagged Products

In the first set of experiments (individual expression system; His-tagged), the APE1832.1-F and APE1832.1-R (same as APES060-RPstI) primers were used for APE1832.1 amplification, and the APE1823-F and APE1823-RPstI primers for APE1823 amplification (Table 1) (Sigma-Proligo; The Woodlands, TX, USA). The annealing temperature was $65^{\circ} \mathrm{C}$. For the second set of experiments (co-expression of both Albal and Alba2), the APE1832.1-F-NdeI and APE1832.1-R-BgIII primers were used for APE1832.1 amplification, and the APE1823-F-BamHI and APE1823-R-PstI primers for APE1823 amplification (Table 1). The first set of experiments with His-tagged Alba protein production included PCR products cloned into the pQE30 plasmid (ampicillin resistance; $N$-terminus His-tagged), while the second set of experiments included co-expression of both of the Alba proteins. Both of the sequences were cloned into the pETDuet-1 vector (Novagen). When coexpressing, APE1823 was cloned into multiple cloning site 1 (MCS 1), which contains the His-tagged sequence, while APE1832.1 was cloned into MCS 2.

For the first and second set of experiments, all of the plasmids were first transformed into the JM109 or DH5 $\alpha$ E. coli strains, and later transformed into their specific E. coli expression strains: M15 for Alba1, and BL21 (DE3) pLysS for Alba2 (both with TransformAid kits, Fermentas). The plasmids were checked for inserts with restriction and PCR analysis. All of the inserts were also sequenced (Microsynth, Macrogen), to confirm that error-free constructs were inserted into the cells.

\section{Protein Expression}

Before the large scale protein expression, a series of optimisation experiments were carried out regarding: (i) different media (minimal media, LB, 2YT); (ii) different times of induction and times of expression after induction with isopropyl $\beta$-D-thiogalactoside (IPTG) $(1,2,4$ and 10 h); (iii) different concentrations of IPTG $(0.25,0.5,1$, and $2 \mathrm{mM}$ ); and (iv) different temperatures of expression of the proteins after induction $\left(25,37\right.$, and $\left.46^{\circ} \mathrm{C}\right)$. 


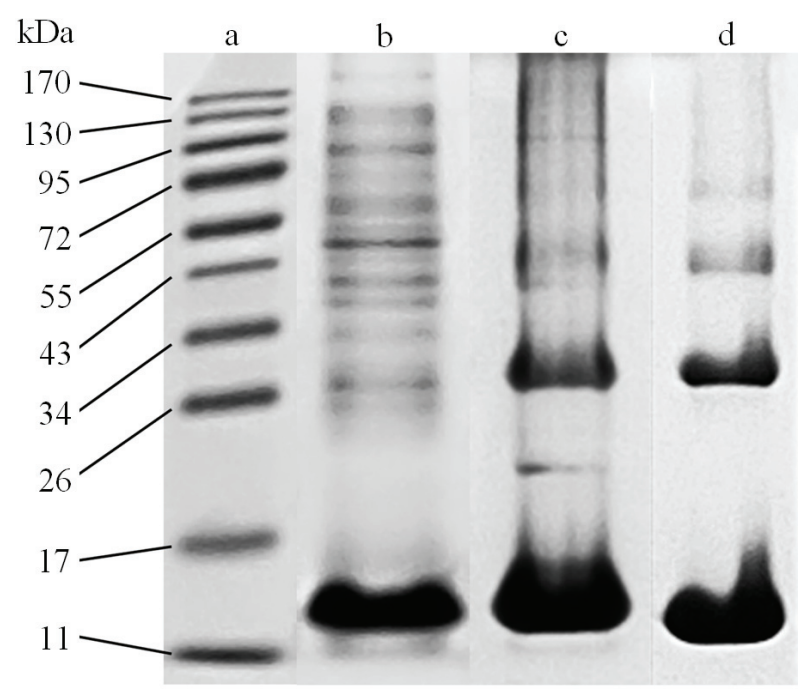

Figure 1. Representative SDS PAGE (20\% gel) following the separate steps of purification of the Albal protein expressed in BL21(DE3)pLysS E. coli strain. Lanes: (a) standard protein ladder, as indicated on left; (b) cleared cell lysate; (c) eluate after Ni-NTA affinity chromatography, for the Albal protein; and (d) the purified Alba1 protein. $10 \mu \mathrm{L}$ of protein sample was applied per lane, gel was stained with comassie blue.

\section{Protein Purification}

\section{Ni-NTA Purification}

After centrifugation, the cells were resuspended in lysis buffer $\left(50 \mathrm{mM} \mathrm{NaH} \mathrm{PO}_{4}, 300 \mathrm{mM} \mathrm{NaCl}, 10 \mathrm{mM}\right.$ imidazole, $\mathrm{pH}=8.0)$, Triton X100 $\left(2 \mu \mathrm{L} \mathrm{g}^{-1}\right.$ biomass $)$, lysozyme $\left(1 \mathrm{mg} \mathrm{mL}^{-1}\right)$, RNase $\left(10 \mu \mathrm{g} \mathrm{mL}^{-1}\right)$ and DNase $\left(5 \mu \mathrm{g} \mathrm{mL}^{-1}\right)$ and incubated on ice for $1 \mathrm{~h}$. The cells were disrupted by sonication, with $30 \mathrm{~s}$ on / $30 \mathrm{~s}$ off pulses for 12 cycles at $4{ }^{\circ} \mathrm{C}$, at $40 \%$ power (Sonics, VCX750). The resulting lysates were centrifuged three times at $17000 \times \mathrm{g}$ for $15 \mathrm{~min}$, to clear them prior to binding to the Ni-NTA slurry (QIAgen). The cleared lysates were incubated with Ni-NTA for $1 \mathrm{~h}$ at $4{ }^{\circ} \mathrm{C}$, and the mixture was then poured into columns and left to sit for $15 \mathrm{~min}$. The slurry was washed several times with wash buffer (50 mM NaH $\mathrm{PO}_{4}, 300 \mathrm{mM} \mathrm{NaCl}, 20 \mathrm{mM}$ imidazole, $\mathrm{pH}=8.0)$ before the protein was eluted with elution buffer $\left(50 \mathrm{mM} \mathrm{NaH} \mathrm{PO}_{4}, 300 \mathrm{mM} \mathrm{NaCl}, 250 \mathrm{mM}\right.$ imidazole, $\mathrm{pH}=8.0$ ).

\section{Precipitation with Ammonium Sulfate}

Precipitation with $80 \%\left(\mathrm{NH}_{4}\right)_{2} \mathrm{SO}_{4}$ was used for partial purification of minor protein impurities and for buffer exchange for the purification of the Alba1 and Alba2 proteins (precipitation of proteins, and re-dissolving in new buffer).

\section{FPLC Purification}

The partially purified Albal protein (after Ni-NTA purification) was additionally purified with an Äkta FPLC system. Prior to FPLC, the Albal protein sample was first dialysed against $50 \mathrm{mM} \mathrm{NaH} \mathrm{PO}_{4}, \mathrm{pH}=7.0$. Samples were first applied to ion-exchange chromatography (MonoS HR 5/5), and selected fractions were then applied to size-exclusion chromatography (Superdex 75 HR 10/30).

\section{Ultrafiltration}

Partially purified samples obtained after $\left(\mathrm{NH}_{4}\right)_{2} \mathrm{SO}_{4}$ precipitation were further purified by ultrafiltration. Filters of the different molecular weight cut-offs (MWCOs) of 3 $\mathrm{kDa}, 30 \mathrm{kDa}$ and $50 \mathrm{kDa}$ (Amicon and Centricon, Millipore) were used to remove impurities with molecular weights significantly different than those of the Alba proteins. Ultrafiltration (MWCO, $3 \mathrm{kDa}$ ) was used for both buffer exchange and sample concentration.

\section{Freezing/High Temperatures}

Thirty min incubations at 80 to $90{ }^{\circ} \mathrm{C}$ of the samples obtained after ultrafiltration were used to remove the final protein impurities. When thermal treatment and freezing were combined, each procedure included 10 consecutive incubations (at $10 \mathrm{~min}$ intervals).

\section{Sodium Dodecyl Sulfate Polyacrylamide Gel Electrophoresis}

All of the fractions and samples were checked throughout the different isolation steps using $20 \%$ sodium dodecyl sulfate polyacrylamide gel electrophoresis (SDS-PAGE) (Bio-Rad Mini-Protean 3). The purified Alba proteins were also analysed by liquid chromatography-tandem mass spectrometry (LC/MS-MS).

\section{Agarose Gel Mobility-shift Assay}

The agarose gel mobility-shift assays (EMSAs) were used to examine the binding of Albal and Alba2 to linear DNA molecules. ${ }^{16}$ Different molar ratios of the Alba proteins to $2686 \mathrm{bp}$ linearised DNA (pUC19/EcoRI) were used. The DNA bp:protein molar ratios ranged from 10:1 to $1: 1$. All of the DNA/Alba protein mixtures were incubated for $1 \mathrm{~h}$ at room temperature (or at $50{ }^{\circ} \mathrm{C}$ ) prior to the EMSAs, with $0.8 \%$ agarose gels used. All EMSAs were performed at room temperature by using $50 \mathrm{mM} \mathrm{NaH} \mathrm{NO}_{4}$ as a binding buffer with $\mathrm{pH}=8.0$.

\section{RESULTS AND DISCUSSION}

With the aim of preparing the recombinant Alba proteins, several combinations of expression systems, growth temperatures and purification protocols were examined. Different combinations of culture growth temperatures $\left(25,37\right.$, and $\left.46{ }^{\circ} \mathrm{C}\right)$ and vectors (Histagged, GST-tagged) were used, according to previously described protocols. ${ }^{3,17-21}$ Here, we describe the optimal expression and purification protocols for the two Alba proteins from $A$. pernix. 


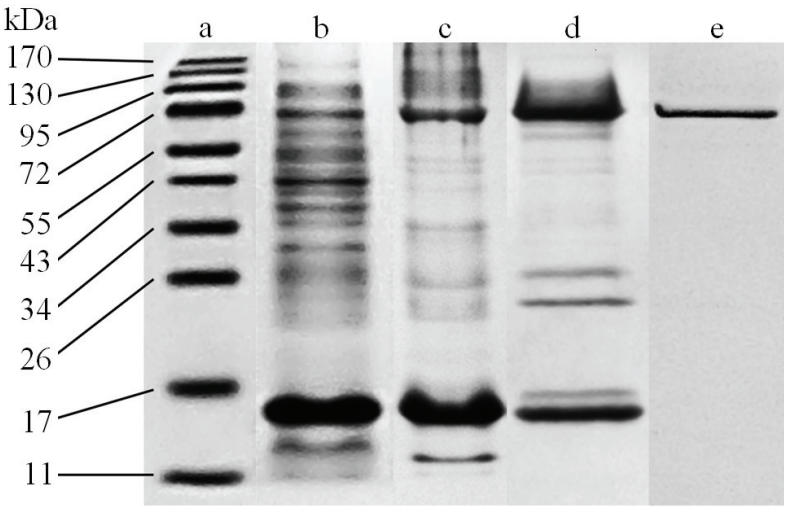

Figure 2. Representative SDS PAGE (20\%) following the separate steps of purification of the Alba2 protein expressed in pQE-30 UA/ M15 E. coli. Lanes: (a) standard protein ladder, as indicated on left; (b) cleared cell lysate; (c) eluate after Ni-NTA affinity chromatography; (d) sample after purification by ultrafiltration (membranes with pore diameter 3-50 kDa); and (e) the GroEL protein after elution from ion exchange and size exclusion chromatography. $10 \mu \mathrm{L}$ of protein sample was applied per lane, gel was stained with comassie blue.

At first, the Alba proteins were expressed as GSTtagged products by applying heterologous expression in E. coli, which resulted in relatively low protein yields due to low protein solubility. Therefore, His-tagged protein expression systems (not shown) were used for both of the Alba proteins.

To increase the protein yield with the use of these His-tagged expression systems, we investigated the effects of different growth media, growth temperatures and IPTG concentrations. The highest protein yield was obtained when the cells were grown in LB medium, at $37{ }^{\circ} \mathrm{C}$ before induction, and at $46{ }^{\circ} \mathrm{C}$ after induction. Induction of protein expression was achieved with 1 mM IPTG (final concentration) at an optical density at $600 \mathrm{~nm}\left(\mathrm{OD}_{600}\right)$ of 0.6 . Higher protein solubility but lower biomass yield was obtained by growing the $E$. coli cells at the marginal growth temperature of $46{ }^{\circ} \mathrm{C}$ for $10 \mathrm{~h}$ after the induction of protein synthesis with 1 mM IPTG. ${ }^{19}$

\section{The Alba1 Protein}

After cell lysis (Figure 1, lane b), the cleared supernatant was purified using Ni-NTA chromatography (Figure 1 , lane c) and was then additionally purified using ion-exchange FPLC (Mono $\mathrm{S}^{\mathrm{TM}}$ HR 5/5). The fractions containing the Albal protein were further purified using size-exclusion FPLC (Superdex $75 \mathrm{HR}$ ). Selected fractions were precipitated with $80 \%$ ammonium sulfate and dissolved in $50 \mathrm{mM} \mathrm{NaH}{ }_{2} \mathrm{PO}_{4}(\mathrm{pH}=7.0)$, to eliminate impurities. Residual E. coli protein contaminants were removed by a $30 \mathrm{~min}$ incubation at $80^{\circ} \mathrm{C}$, due to the thermal denaturation of these bacterial proteins.

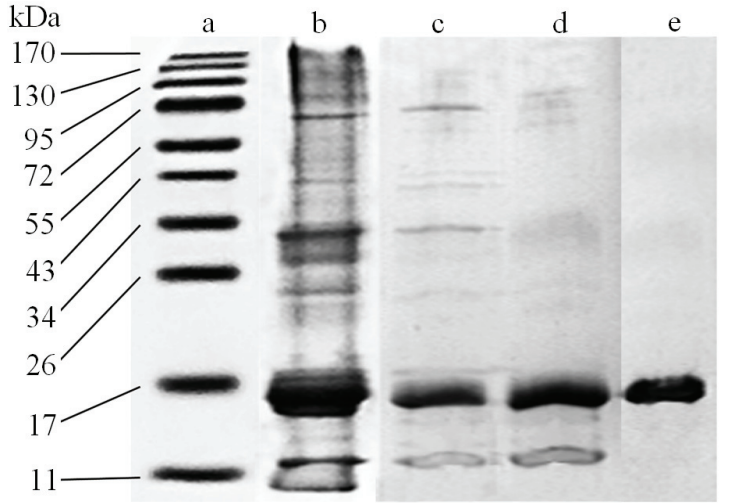

Figure 3. Representative SDS PAGE (20\%) following the separate steps of purification of the Alba2 protein expressed in the pETDuet-1/ BL21 E. coli system. Lanes: (a) standard protein ladder, as indicated on left; (b) eluate after Ni-NTA affinity chromatography; (c) soluble fraction after Ni-NTA chromatography followed by precipitation with $80 \%$ (NH4) $)_{2} \mathrm{SO}_{4}$; (d) as for lane (c), plus incubation at $80{ }^{\circ} \mathrm{C}$ for 30 min; and (e) the purified Alba2 protein after the second Ni-NTA chromatography. $10 \mu \mathrm{L}$ of protein sample was applied per lane, gel was stained with comassie blue.

SDS-PAGE examination of the samples revealed no other impurities (Figure 1, lane d). The final yield achieved was approximately 1.0 to $1.5 \mathrm{mg}$ protein $\mathrm{L}^{-1}$ E. coli culture. The bands that corresponded to the molecular mass of approximately 30,40 , and $70 \mathrm{kDa}$ in Figure 1 (lane d) represented the oligomers of the Alba1 protein. The molecular mass of purified Albal determined by SDS-PAGE was approximately $13 \mathrm{kDa}$ (Figure 1, lane d). The more accurate molecular mass determined by LC/MS-MS was 10387 Da for Alba1. The reason for these aberrancy in molecular mass can be assigned to influence of protein tertiary structure (and disulphide bonds) still present to some extent in SDS PAGE mass determination.

\section{The Alba2 Protein}

\section{Purification of Alba2 Expressed in pQE30}

The Alba2 protein expressed in the M15/pQE30 UA $E$. coli system was purified with the same purification protocol as for Alba1. The Ni-NTA purification was relatively successful. However, in the processes that followed, an approximately $70 \mathrm{kDa}$ protein identified as GroEL by LC/MS-MS (Aberdeen Proteomics, UK) persisted as a contaminant throughout the purification (Figure 2, lane e). Due to the constant precipitation of the Alba2 protein, the purification almost always resulted in GroEL and virtually no Alba2 protein (Figure 2, lane e). Additional partial purification with ultrafiltration (MWCOs from 3 to $50 \mathrm{kDa}$ ) was also not successful (Figure 2, lane d). 


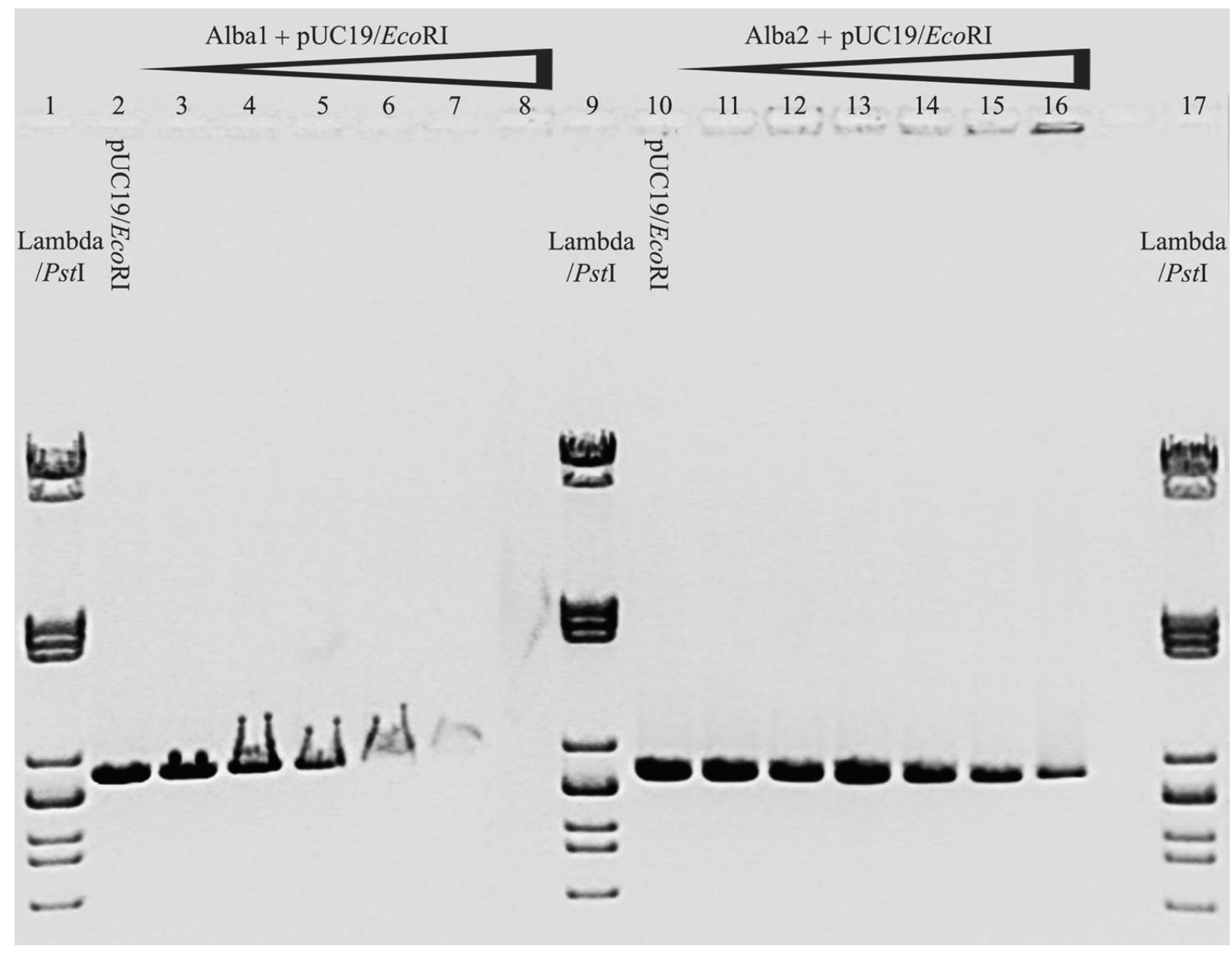

Figure 4. Representative electrophoretic mobility shift assay showing the influence of the Alba protein binding to the electrophoretic mobility of the linear DNA (pUC19/EcoRI). The concentrations of the added Alba proteins increase from left to right (DNA bp:protein ratios from 10:1 to 1:1). Lanes 2 and 10 represent linear DNA (pUC19/EcoRI) in the absence of the Alba proteins; lanes 3-8 represent the DNA with the bound Alba1 protein; lanes 11-16 represent the DNA with the bound Alba2 protein; lanes 1,9 and 17 represent the DNA standards $(\lambda / P s t \mathrm{I})$. In binding assay $2 \mu \mathrm{L}$ of $0.24 \mathrm{mM}$ linear DNA per each well was used, retardation effect on DNA in EMSA was visualised with ethidium bromide.

Purification of Co-expressed Alba2 From pETDuet-1

A co-expression system was used for both of the Alba proteins so as to minimise the interactions between Alba2 and the GroEL protein. In that case, E. coli cells lysate with Alba2 co-expressed with Alba1 was first purified by Ni-NTA chromatography. In addition to the major impurities, the greater part of the Albal protein was removed from the sample prior to elution of Alba2 (Figure 3, lane b). Alba2 protein was His-tagged, while Alba1 protein was not, therefore it was washed away with other impurities. The elution fractions with the Alba1 and Alba2 proteins were further precipitated with $80 \%\left(\mathrm{NH}_{4}\right)_{2} \mathrm{SO}_{4}$. The pellet was then resuspended in Ni-NTA lysis buffer (Figure 3, lane c), and the sample was incubated at $80^{\circ} \mathrm{C}$ for $30 \mathrm{~min}$ to remove impurities. The supernatant (Figure 3, lane d) was then again incubated with the Ni-NTA slurry (described above), to remove residues of non-His-tagged Alba1 protein. Frac- tions containing the Alba2 protein in Ni-NTA elution buffer were further precipitated with $80 \%\left(\mathrm{NH}_{4}\right)_{2} \mathrm{SO}_{4}$. The pellet was resuspended in $50 \mathrm{mM} \mathrm{NaH} \mathrm{PO}_{4}$ buffer $(\mathrm{pH}=7.0)$. The final yield achieved was 1.0 to $1.5 \mathrm{mg}$ Alba2 protein $\mathrm{L}^{-1}$ E. coli culture (Figure 3, lane e). The molecular mass of purified Alba2 determined by SDSPAGE was approximately $16 \mathrm{kDa}$ (Figure 2, lane e). The more accurate molecular mass, determined by LC/MS-MS was 11847 Da for Alba2.

Based on the experimental conditions tested, we concluded that the best protein yield for Albal was obtained when it was expressed in M15/pQE30 E. coli and grown at $46^{\circ} \mathrm{C}$ for $10 \mathrm{~h}$ after induction with $1 \mathrm{mM}$ IPTG $(0.5 \mathrm{~L}$ medium in $2 \mathrm{~L}$ flasks, at $200 \mathrm{rpm})$. The best yield of Alba2 was obtained when it was co-expressed with Alba1 in BL21/pETDuet-1 E. coli, to avoid contamination of the final sample with GroEL. The growth conditions were the same as for Albal. 


\section{DNA Binding Ability}

The binding of the Alba proteins to linearised DNA (pUC19/EcoRI) resulted in delayed DNA mobility, as shown in Figure 4. When the Albal protein was added to DNA (DNA bp:protein ratios from 10:1 to 1: 1), it bound the DNA molecules and resulted in a shift in the electrophoretic mobility of the DNA (Figure 4, lanes $3-8)$. In the case of the Alba2 protein binding to DNA, a condensation/ delaying effect was seen, rather than an actual gel shift; as the DNA bands faded away, the DNA could not exit the loading wells of the gel (Figure 4, lanes 11-16). When the critical ratios of DNA bp:protein were exceeded, both of the Alba proteins promoted DNA condensation, which prevented the DNA from moving through the electrophoresis gel. No apparent differences in the electrophoretic mobilities were seen when the Alba proteins and the DNA were mixed and incubated prior to an EMSA at $50{ }^{\circ} \mathrm{C}$ (data not shown). Results of the protein/ DNA binding obtained were similar to those seen for other Alba/DNA gel mobility shift assays, where DNA delaying was seen. ${ }^{6,9,10,14,22}$ There was a delaying effect of Albal binding to the DNA, followed by a precipitating effect when the critical DNA bp:protein molar ratio was exceeded $(>2: 1)$. For Alba2, precipitation of DNA $(>10: 1)$ was observed primarily. The possible reason for the differences in the gel mobility delays between Alba1 and Alba2 might be attributed to the different physiological functions of these two Alba proteins in hyperthermophilic archaea, since Albal is usually produced to significantly greater levels (95\%), compared to Alba2 (5\%).

\section{CONCLUSIONS}

Two Alba proteins (Alba1 and Alba2) originating from hyperthermophilic archaeon Aeropyrum pernix have been cloned, heterologously expressed and purified.

Growing the E. coli, transformed with plasmid constructs encoding for Alba1 and/or Alba2, at temperatures $<46{ }^{\circ} \mathrm{C}$ after IPTG induction (1 mM IPTG) resulted in lower protein yields. Longer growth times $(10 \mathrm{~h})$ at $46^{\circ} \mathrm{C}$ were needed, as the biomass growth at $46^{\circ} \mathrm{C}$ was much slower when compared with the growth at $37^{\circ} \mathrm{C}$.

Taking the current procedures into consideration, ${ }^{3,17-21}$ the His-tagged Alba proteins reduced isolation steps and suited purification better than the nonHis-tagged products, as the GST-tagged constructs did not produce the soluble Alba proteins. Co-expression of both of the Alba proteins was needed when isolating recombinant Alba2. Our data suggest that the use of ion-exchange and size-exclusion chromatography is not necessary for purification of the Alba proteins. The electrophoretic mobility shift assay demonstrated the ability of the Alba1 and Alba2 proteins from Aeropyrum pernix to bind DNA, although further investigations will be needed to define the interactions in detail and to characterise the physological roles of these Alba proteins.

Acknowledgements. The authors would like to thank Dr. Zdravko Podlesek for providing the pUC19 plasmid. This study was supported financially by The Ministry of Education, Science and Sport of the Republic of Slovenia (Research programme: Biochemical and biophysical-chemical characterisation of natural compounds: P4-0121).

\section{REFERENCES}

1. C. R. Woese, O. Kandler, and M. L. Wheelis, Proc. Natl. Acad. Sci. U. S. A. 87 (1990) 4576-4579.

2. H. Grosjean and T. Oshima, How nucleic acids cope with high temperature, in: C. Gerday and N. Glansdorff (Ed.), Physiology and biochemistry of extremophiles, Blackwell Publishing, Oxford, 2007, pp. 36-56

3. Kumarevel, K. Sakamoto, S. C. Gopinath, A. Shinkai, P. K. Kumar, and S. Yokoyama, Proteins 71 (2007) 1156-1162.

4. Y. Sako, N. Nomura, A. Uchida, Y. Ishida, H. Morii, Y. Koga, T. Hoaki, and T. Maruyama, Int. J. Syst. Bacteriol. 46 (1996) 1070-1077.

5. K. Sandman and J. N. Reeve, Curr. Opin. Microbiol. 8 (2005) 656-661.

6. C. Jelinska, M. J. Conroy, C. J. Craven, A. M. Hounslow, P. A. Bullough, J. P. Waltho, G. L. Taylor, and M. F. White, Structure 13 (2005) 963-971.

7. R. Lurz, M. Grote, J. Dijk, R. Reinhardt, and B. Dobrinski, EMBO J. 5 (1986) 3715-3721.

8. P. Mallick, D. R. Boutz, D. Eisenberg, and T. O. Yeates, Proc. Natl. Acad. Sci. U. S. A. 99 (2002) 9679-9684.

9. H. Xue, R. Guo, Y. F. Wen, D. X. Liu, and L. Huang, J. Bacteriol. 182 (2000) 3929-3933.

10. X. Luo, U. Schwarz-Linek, C. H. Botting, R. Hensel, B. Siebers, and M. F. White, J. Bacteriol. 189 (2007) 403-409.

11. L. Aravind, L. M. Iyer, and V. Anantharaman, Genome Biology 4 (2003) R64

12. ExPASy. ExPASy Proteomics Server. Swiss Institute of Bioinformatics. (2008) [Online.]

13. V. Biou, F. Shu, and V. Ramakrishnan, EMBO J. 14 (1995) 4056-4064.

14. B. N. Wardleworth, R. J. M. Russell, S. D. Bell, G. L. Taylor, and M. F. White, EMBO J. 21 (2002) 4654-4662.

15. D. G. Pitcher, N. A. Saunders, and R. J. Owen, Lett. Appl. Microbiol. 8 (1989) 151-156.

16. J. Sambrook and D. W. Russel, Gel retardation assay, in: Molecular Cloning: A Laboratory Manual 3rd Ed., Vol. 3, Cold Spring Harbor Laboratory Press, Cold Spring Harbor (NY), 2001, pp. 17.13-17.16.

17. M. J. Teale, M. Kahsai, S. K. Singh, S. P. Edmondson, R. Gupta, J. W. Shriver, and E. Meehan, Acta Crystallogr. D: Biol. Crystallogr. 59 (2003) 1320-1322.

18. G. G. Wang, R. Guo, M. Bartlam, H. Xue, H. T. Yang, Y. W. Liu, L. Huang, and Z. H. Rao, Acta Crystallogr. D: Biol. Crystallogr. 58 (2002) 1240-1242.

19. D. Koma, T. Sawai, S. Harayama, and K. Kino, Appl. Microbiol. Biotechnol. 73 (2006) 172-180.

20. B. N. Wardleworth, R. J. M. Russell, M. F. White, and G. L. Taylor, Acta Crystallogr. D: Biol. Crystallogr. 57 (2001) 1893-1894.

21. Q. Cui, Y. F. Tong, H. Xue, L. Huang, Y. G. Feng, and J. F. Wang, J. Biol. Chem. 278 (2003) 51015-51022.

22. V. L. Marsh, S. Y. Peak-Chew, and S. D. Bell, J. Biol. Chem. 280 (2005) 21122-21128. 